\title{
Improved Efficiency of Polymer-Fullerene Bulk Heterojunction Solar Cells by the Addition of $\mathrm{Cu}$ (II)-Porphyrin-Oligothiophene Conjugates
}

Dani M. Stoltzfus ${ }^{a}$, Jurgen Kesters ${ }^{b, c}$, Mathias Kelchtermans $^{b, c}$, Pieter Verstappen ${ }^{b, c}$, Ilaria Cardinaletti $^{d}$, Rob Cornelissen ${ }^{e}$, Jan D'Haen ${ }^{c, d}$, Laurence Lutsen ${ }^{c}$, Dirk Vanderzande ${ }^{b, c}$, Jean Manca $^{e}$, Christopher W. Bielawskit, ${ }^{f, g}$,Wouter Maes ${ }^{b, c} *$, Jonathan L. Sessler ${ }^{a, h} *$

${ }^{a}$ Department of Chemistry and Biochemistry, The University of Texas at Austin, Austin, TX 78712-1224, USA

${ }^{\mathrm{b}}$ Design \& Synthesis of Organic Semiconductors (DSOS), Institute for Materials Research (IMO), Hasselt University, Agoralaan 1 - Building D, 3590 Diepenbeek, Belgium; E-mail: wouter.maes@uhasselt.be

${ }^{\mathrm{c}}$ IMOMEC Division, IMEC, Wetenschapspark 1, 3590 Diepenbeek, Belgium

${ }^{\mathrm{d}}$ Material Physics Division, Institute for Materials Research (IMO), Hasselt University, Wetenschapspark 1, 3590 Diepenbeek, Belgium

${ }^{\mathrm{e}}$ X-LaB, Hasselt University, Agoralaan 1 - Building D, 3590 Diepenbeek, Belgium

${ }^{\mathrm{f}}$ Institute for Basic Science (IBS), Center for Multidimensional Carbon Materials (CMCM), Ulsan, Republic of Korea

${ }^{\mathrm{g}}$ Department of Chemistry and Department of Energy Engineering, Ulsan National Institute of Science and Technology (UNIST), Ulsan, Republic of Korea

${ }^{\mathrm{h}}$ Department of Chemistry, Shanghai University, Shanghai, Peoples Republic of China; Email: sessler@cm.texas.edu 


\begin{abstract}
Ternary organic photovoltaic devices were prepared through the addition of small amounts of metalloporphyin-terthiophenes to two established low bandgap polymer:fullerene blends. The methodology afforded a PCDTBT:PC ${ }_{71} \mathrm{BM}$-based device that displayed an initial power conversion efficiency of $5.1 \%$, an increase of $16 \%$ when compared to the binary blend. Among the range of metalloporphyrins considered in this study, the $\mathrm{Cu}(\mathrm{II})$-porphyrin derivatives were found to result in the most significant efficiency improvements.
\end{abstract}

\title{
Keywords
}

Porphyrins; Organic photovoltaics; Bulk heterojunctions; Low bandgap polymers; Ternary blends

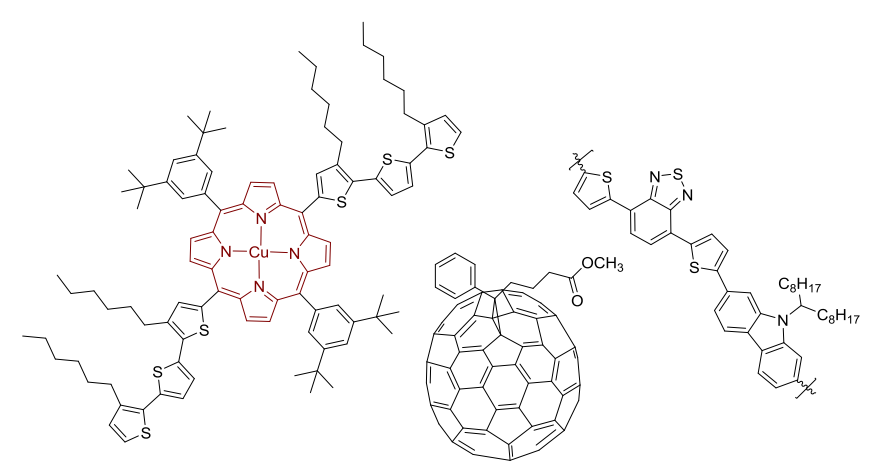




\section{Introduction}

Many of the emerging thin-film solar cell technologies show strong potential for renewable energy production. Among these, organic photovoltaics (OPV) exhibit a number of particularly attractive features, such as mechanical flexibility, (semi)transparency, color tunability, enhanced low-light (e.g., in-house) operation, positive temperature coefficients and compatibility with large scale (e.g., roll-to-roll) processing techniques. ${ }^{[1]}$ At present, the power conversion efficiencies (PCE's) of single junction bulk heterojunction (BHJ) polymer solar cells, in which the single photoactive layer consists of a blend of an electron donating (low optical gap type) conjugated polymer and a fullerene-based electron acceptor, have surpassed the $10 \%$ threshold value, enabling market entrance and encouraging continued development activities. ${ }^{[2,3]}$ The impressive progress in the field in recent years has been realized through judicious efforts in novel material designs and deployment, optimization of the processing conditions, ${ }^{[4]}$ and extensive device optimization, for example through the implementation of suitable interfacial layers ${ }^{[5]}$.

One approach to increase the coverage of the solar spectrum and thereby device efficiency involves the use of tandem devices, in which two complementary absorbing photoactive layers are combined. ${ }^{[6]}$ To simplify the device stack and to reduce costs, an even more appealing strategy embodies the use of ternary blends in which (usually) two complementary absorbing electron donor components are blended together with the electron acceptor in a single photoactive layer in a manner that maintains a single junction. ${ }^{[7]}$ As such, ternary blend photovoltaic devices consisting of PTB7-TH, $p$-DTS(FBTTH $)_{2}$ and $\mathrm{PC}_{71} \mathrm{BM}$ have recently exhibited a PCE of $10.5 \% .{ }^{[7 \mathrm{e}]}$ Ternary blend organic solar cells have also been shown to afford increased fill factors (FF's) and short-circuit current densities ( $J_{\mathrm{SC}}$ 's) due to the rapid transfer of photo-generated positive polarons from a low optical gap polymer phase (Si-PCPDTBT) to a wider gap polymer phase (P3HT). ${ }^{[\mathrm{b}]}$ An important challenge, however, is to optimize the active layer morphologies displayed by the three-component blends.

Porphyrins and related oligopyrrolic macrocycles (collectively porphyrinoids) have been successfully used in the field of dye-sensitized solar cells for a number of years. ${ }^{[8]}$ Recently, these chromophores have become increasingly popular for use in the construction of BHJ OPV devices. ${ }^{[9,10]}$ Porphyrinoids generally display high extinction coefficients and show good thermal and oxidative stability. Moreover, their photo- and electrochemistry can be tuned through functionalization of the periphery (meso and $\beta$-positions) and/or variation of the metal center. In principle, this allows key fundamental properties, including light harvesting, 
solubility, miscibility, charge transfer and charge carrier transport, to be optimized. Both polymer and small molecule electron donor porphyrin-based materials have recently demonstrated high OPV performances (with PCE's of up to $8.6 \%$ ). ${ }^{[9,10]}$ In parallel, porphyrins have also been explored as potential electron acceptors with the aim of replacing fullerenes. ${ }^{[11]}$ Due to their absorptivity over a broad wavelength range (up to the near-IR), materials based on porphyrinoids have also been proposed as suitable candidates for ternary blend organic solar cells. Belcher and co-workers demonstrated that the addition of simple porphyrins to MEH-PPV:PC ${ }_{61} \mathrm{BM}$ and $\mathrm{P} 3 \mathrm{HT}: \mathrm{PC}_{61} \mathrm{BM}$ active layers resulted in an extra contribution to the photocurrent of the devices, an effect ascribed to a broadening of the absorption spectrum. ${ }^{[12]}$ Unfortunately, the PCE values for these latter systems remained low, below those measured for devices containing binary blends. This operational deficiency was attributed to the porphyrins acting as recombination sites. Other recent work has served to demonstrate that solar cells based on $\mathrm{P} 3 \mathrm{HT}: \mathrm{PC}_{61} \mathrm{BM}$ blends containing $\mathrm{Cu}(\mathrm{II})$-porphyrins as ternary components can exhibit limited fullerene crystallization and phase segregation and thus an enhanced thermal stability. ${ }^{[13]}$

In a previous study, we demonstrated that pre-designed metalloporphyrin-oligothiophene conjugates (Figure 1) added value to $\mathrm{P} 3 \mathrm{HT}: \mathrm{PC}_{61} \mathrm{BM}$ solar cells when used as ternary blend components. ${ }^{[14]}$ The PCE was significantly increased (up to 17\%) upon the addition of a small amount (1-10\%) of $\mathrm{Cu}(\mathrm{II})$-porphyrin and key differences were observed depending on the central metal ion. In the present study, this strategy is extended to polymer solar cells employing less crystalline, low optical gap electron donor copolymers to improve device efficiencies. To this end, we selected PCDTBT (poly\{[N-9'-heptadecanyl-2,7-carbazole]-alt5,5-[4',7'-di(thien-2-yl)-2',1',3'-benzothiadiazole]\}, a 'workhorse' amorphous polymer used in OPV devices, ${ }^{[15]}$ and PCPDT-DTTzTz (poly $\left\{\left[4-\left(2^{\prime}\right.\right.\right.$-ethylhexyl)-4-octyl-4H-cyclopenta[2,1$\left.b: 3,4-b^{\prime}\right]$ dithiophene-2,6-diyl]-alt-[2,5-di(3'-hexylthiophen-2'-yl)thiazolo[5,4- $\left.d\right]$ thiazole-5',5"diyl]\}), a semi-crystalline polymer, as donors (Figure 1). ${ }^{[16]} \mathrm{PC}_{71} \mathrm{BM}$ ([6,6]-phenyl- $\mathrm{C}_{71^{-}}$ butyric acid methyl ester) was employed as the electron acceptor to maximize efficiencies. 

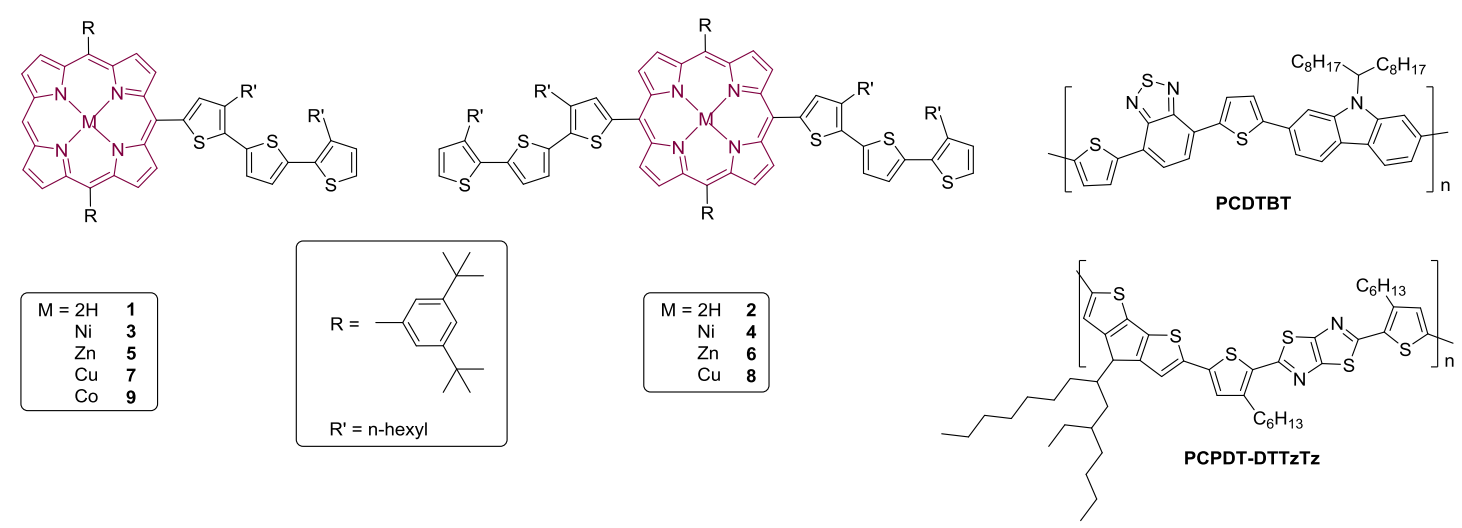

Figure 1. Structures of various porphyrin compounds and conjugated polymers used to prepare ternary blends in combination with $\mathrm{PC}_{71} \mathrm{BM}$.

\section{Results and Discussion}

To investigate the impact of porphyrin structure on the performance of ternary solar cells containing this class of chromophores, standard (glass/ITO/PEDOT:PSS/active layer/Ca/Al) BHJ OPV devices were fabricated. For the photoactive layers, a 5:20:0.1 (wt\%) ratio of PCDTBT, $\mathrm{PC}_{71} \mathrm{BM}$ and the various porphyrin additives (1-9, shown in Figure 1) was employed. The relative proportion of the three blend components was based on the optimized ratio for the binary polymer:fullerene blend ${ }^{[15]}$ and some optimization of the porphyrin quantities based on the optimal quantity used in the P3HT-based ternary blends. ${ }^{[14]}$ The porphyrin derivatives differ in terms of the number of terthiophene meso-substituents and the central metal complexed within the central $\mathrm{N}_{4}$ core. As summarized in Table 1, the photovoltaic output parameters changed significantly as a function of the chosen porphyrin. For all ternary blends measured, a (slight) increase in $J_{\mathrm{SC}}$ was observed, which in some cases was counteracted by a decrease in open-circuit voltage $\left(V_{\mathrm{OC}}\right)$ and/or FF. The addition of the $\mathrm{Cu}(\mathrm{II})$-porphyrin $\mathbf{8}$, however, gave rise to a combination of a significantly enhanced $J_{\mathrm{SC}}(9.8$ vs $8.6 \mathrm{~mA} / \mathrm{cm}^{2}$ for the PCDTBT:PC ${ }_{71} \mathrm{BM}: 8$ and PCDTBT:PC ${ }_{71} \mathrm{BM}$ blends, respectively) with

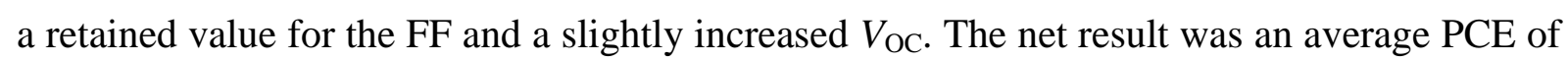
$4.7 \%$ (vs $4.0 \%$ for the reference device) and a maximum efficiency of $5.1 \%$ (Table 1, Figure 2). In contrast, low performances were measured for devices containing either of the free-base porphyrin compounds ( $\mathbf{1}$ or $\mathbf{2}$ ). These contrasting results are consistent with previous observations recorded for $\mathrm{P} 3 \mathrm{HT}: \mathrm{PC}_{61} \mathrm{BM}$ active layers in that the $\mathrm{Cu}$-porphyrins afforded the best results, while the use of free-base porphyrin derivatives reduced the device efficiency. ${ }^{[14]}$ 
Table 1. Summary of the $I-V$ characteristics of the PCDTBT:PC ${ }_{71} \mathrm{BM}$ solar cells with and without incorporated porphyrin derivatives 1-9.

\begin{tabular}{|c|c|c|c|c|c|c|}
\hline & Material blend & $J_{\mathrm{SC}} / \mathrm{mA} \mathrm{cm}^{-2}$ & $V_{\mathrm{OC}} / \mathrm{V}$ & $\mathrm{FF}$ & $\operatorname{PCE}($ Ave $) / \%^{a}$ & PCE(Best) $/ \%$ \\
\hline 1 & PCDTBT:PC ${ }_{71} \mathrm{BM}$ & $8.58( \pm 0.56)$ & $0.84( \pm 0.00)$ & $0.56( \pm 0.01)$ & $4.0( \pm 0.2)$ & 4.3 \\
\hline 2 & PCDTBT:PC ${ }_{71} \mathrm{BM}: 1$ & $8.90( \pm 0.67)$ & $0.58( \pm 0.02)$ & $0.40( \pm 0.01)$ & $2.1( \pm 0.2)$ & 2.4 \\
\hline 3 & PCDTBT:PC ${ }_{71} \mathrm{BM}: 2$ & $9.50( \pm 0.63)$ & $0.59( \pm 0.02)$ & $0.44( \pm 0.02)$ & $2.5( \pm 0.2)$ & 2.8 \\
\hline 4 & PCDTBT:PC ${ }_{71} \mathrm{BM:3}$ & $9.12( \pm 0.23)$ & $0.81( \pm 0.01)$ & $0.43( \pm 0.02)$ & $3.2( \pm 0.1)$ & 3.3 \\
\hline 5 & PCDTBT:PC ${ }_{71} \mathrm{BM}: 4$ & $9.69( \pm 0.47)$ & $0.83( \pm 0.01)$ & $0.48( \pm 0.02)$ & $3.9( \pm 0.2)$ & 4.4 \\
\hline 6 & PCDTBT:PC ${ }_{71} \mathrm{BM}: 5$ & $9.69( \pm 0.72)$ & $0.79( \pm 0.02)$ & $0.48( \pm 0.04)$ & $3.7( \pm 0.4)$ & 4.2 \\
\hline 7 & PCDTBT:PC ${ }_{71}$ BM:6 & $9.47( \pm 0.73)$ & $0.68( \pm 0.03)$ & $0.45( \pm 0.03)$ & $2.9( \pm 0.5)$ & 3.6 \\
\hline 8 & PCDTBT:PC ${ }_{71} \mathrm{BM:7}$ & $9.78( \pm 0.68)$ & $0.79( \pm 0.01)$ & $0.49( \pm 0.02)$ & $3.8( \pm 0.3)$ & 4.2 \\
\hline 9 & PCDTBT:PC ${ }_{71} \mathrm{BM}: 8$ & $9.76( \pm 0.73)$ & $0.86( \pm 0.02)$ & $0.56( \pm 0.00)$ & $4.7( \pm 0.4)$ & 5.1 \\
\hline 10 & PCDTBT:PC ${ }_{71} \mathrm{BM:9}$ & $9.52( \pm 0.57)$ & $0.82( \pm 0.01)$ & $0.50( \pm 0.01)$ & $3.9( \pm 0.3)$ & 4.4 \\
\hline
\end{tabular}

${ }^{a}$ Averaged values over at least 8 devices.

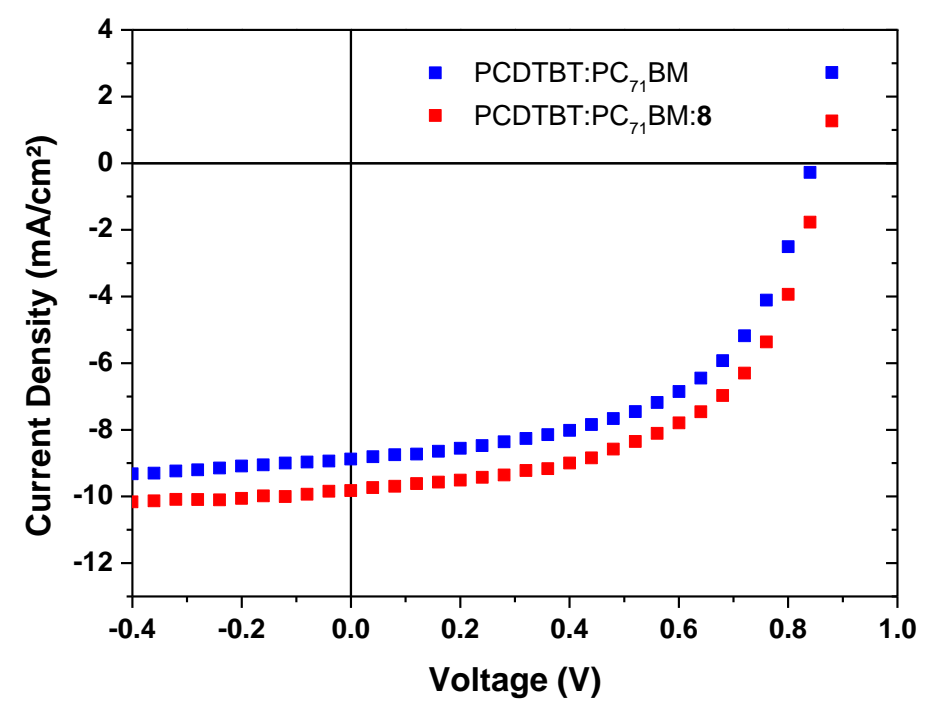

Figure 2. $I-V$ curves for average performing polymer solar cells based on PCDTBT:PC ${ }_{71} \mathrm{BM}$ and PCDTBT:PC ${ }_{71} \mathrm{BM}: 8$.

The external quantum efficiency (EQE) spectrum of the disubstituted $\mathrm{Cu}(\mathrm{II})$-porphyrin based ternary OPV device showed no clear contribution of the porphyrin chromophore to photocurrent generation (Figure 3). However, the incorporated porphyrin compound must influence the charge carrier extraction efficiency in a beneficial manner since the entire EQE spectrum is shifted upward as compared to a reference PCDTBT:PC ${ }_{71} \mathrm{BM}$ device (consistent 
with the $J_{\mathrm{SC}}$ increase). As the porphyrin moiety was added in a very small amount, it is not surprising that its individual absorption features were not apparent in the EQE spectrum. To illustrate this point, the UV-Vis absorption spectra of pristine PCDTBT, Cu-porphyrin $\mathbf{8}$ and a representative PCDTBT:porphyrin 8 (5:0.1) blend (in solution and thin film) were recorded (Figure 4). The absorption spectrum of the pure $\mathrm{Cu}$-porphyrin compound exhibited a strong absorption band at 400-450 $\mathrm{nm}$ (the porphyrin Soret band), which resulted in a small shoulder and slightly increased absorptivity in the blend solution spectrum. However, this effect was less pronounced in the solid state and in the EQE spectrum (as the $\mathrm{PC}_{71} \mathrm{BM}$ is known to absorb over this wavelength range as well).

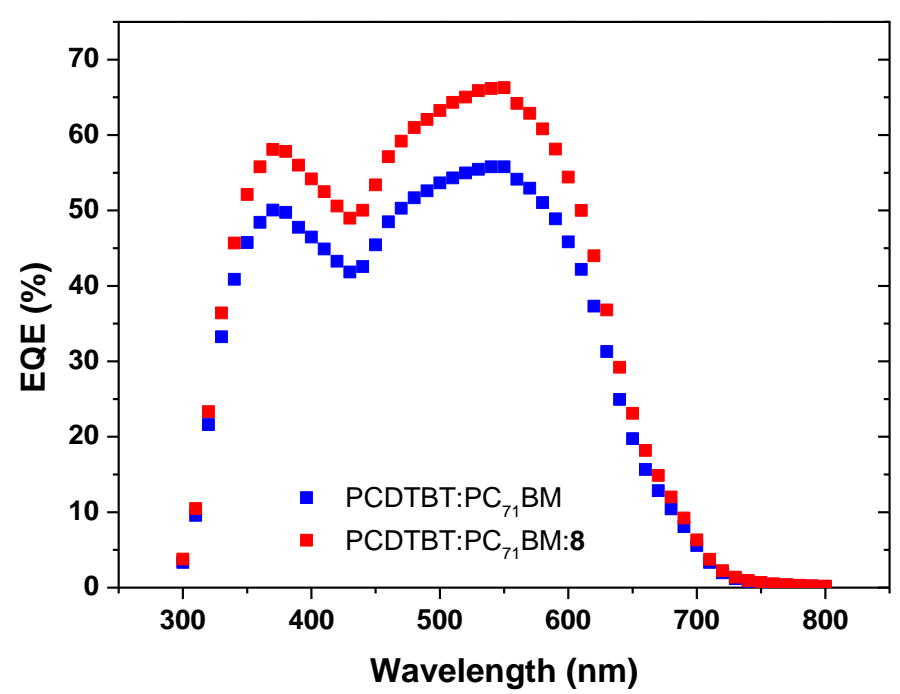

Figure 3. EQE spectra of average performing polymer solar cells containing PCDTBT:PC 71 BM and PCDTBT:PC 71 BM:8. The extracted current densities $\left(J_{\mathrm{EQE}}=9.8\right.$ and $8.3 \mathrm{~mA} / \mathrm{cm}^{2}$ for the devices with and without porphyrin $\mathbf{8}$, respectively) correspond well to the measured $J_{\mathrm{SC}}$ values (Table 1 ). 


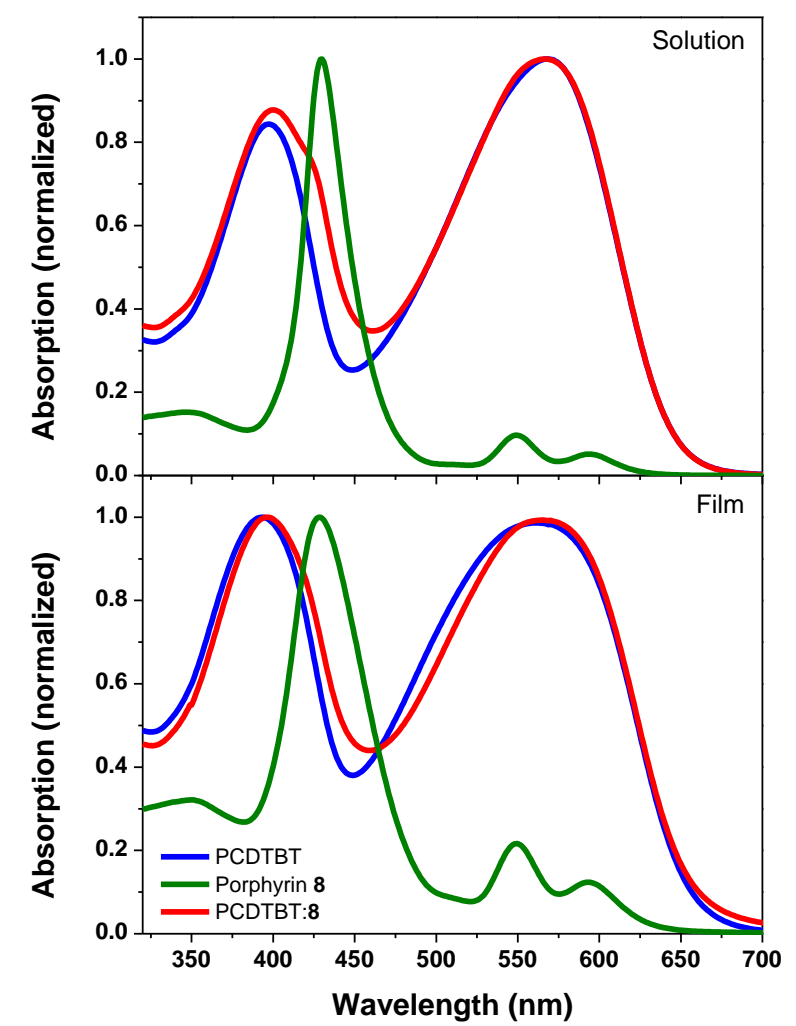

Figure 4. Normalized UV-Vis absorption spectra of pristine PCDTBT, Cu-porphyrin $\mathbf{8}$ and PCDTBT:8 (5:0.1) blend solutions (in chloroform) and films.

The increased $J_{\mathrm{SC}}$ recorded upon incorporation of porphyrin 8 might be related to an enhanced charge carrier mobility. Therefore, field-effect transistor (FET) measurements were initially performed on pristine PCDTBT and PCDTBT:8 blend films to estimate the difference in hole mobility for the two pure electron donor phases. However, the extracted values were found to be similar, $\sim 1.0 \times 10^{-4}$ and $9.4 \times 10^{-5} \mathrm{~cm}^{2} \mathrm{~V}^{-1} \mathrm{~s}^{-1}$ for the pristine PCDTBT and PCDTBT: 8 blend films, respectively (the transfer and output curves are shown in Figure S1). On the other hand, photoinduced charge extraction under linearly increased voltage (photo-CELIV) resulted in mobilities that were measured to be $4.6 \times 10^{-4}$ for the binary blend and $4.3 \times 10^{-4}$ $\mathrm{cm}^{2} \mathrm{~V}^{-1} \mathrm{~s}^{-1}$ for the ternary system, confirming similar charge transport characteristics in the two films (Figure S2). Therefore another explanation was sought.

Another possible origin of the $J_{\mathrm{SC}}$ enhancement is an improved morphology for the donor and acceptor domains within the photoactive layer, which in turn would be expected to promote charge transport and/or charge separation through minimization of recombination losses. To test this latter hypothesis, atomic force microscopy (AFM) and transmission electron 
microscopy (TEM) measurements were performed on the photoactive layer blend films. As illustrated by the images shown in Figure 5, distinct differences were not observed upon incorporation of the $\mathrm{Cu}(\mathrm{II})$-porphyrin 8 in comparison with the reference device. Further evidence for the morphological similarity was provided by the selective area electron diffraction (SAED) patterns accompanying the TEM data (Figure S3), revealing no additional peaks or major changes in the integration spectra.

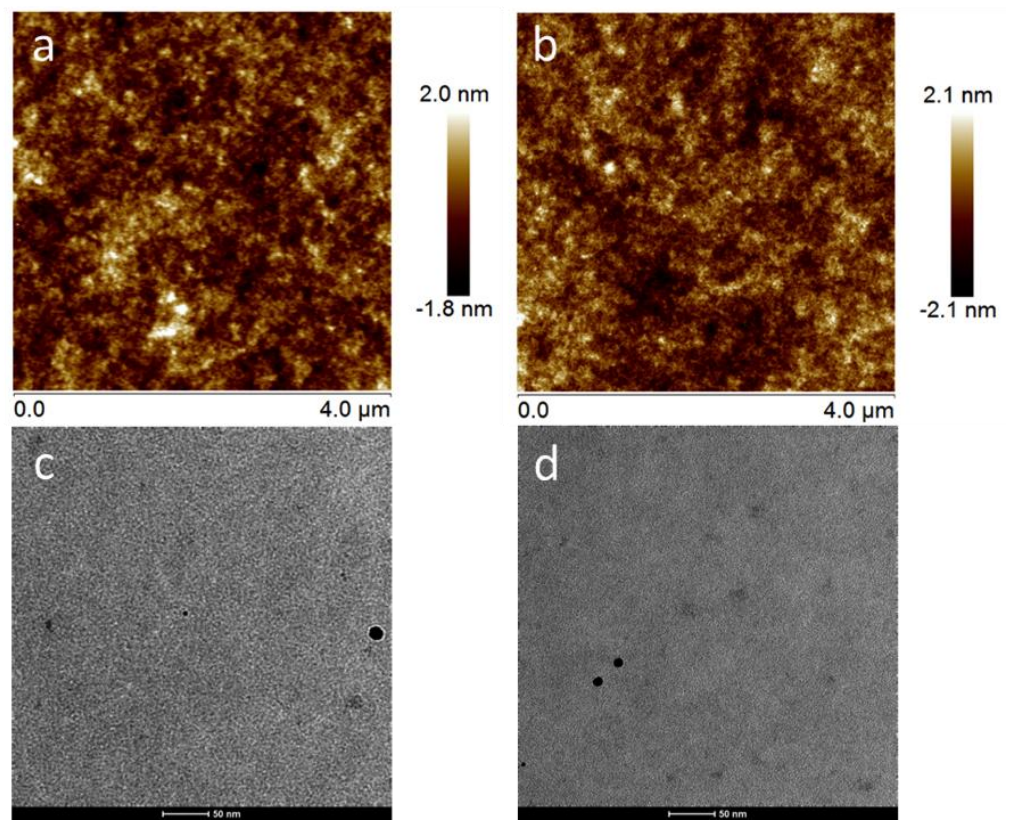

Figure 5. AFM (4 x $4 \mu \mathrm{m}$, top) and TEM (scalebar $50 \mathrm{~nm}$, bottom) images of the photoactive layers of polymer solar cells containing PCDTBT:PC ${ }_{71} \mathrm{BM}(\mathrm{a}, \mathrm{c})$ or PCDTBT:PC ${ }_{71} \mathrm{BM}: 8(\mathrm{~b}, \mathrm{~d})$.

The surface free energy has been used as a tool to elucidate the position of the third component in ternary blend films. ${ }^{[17]}$ To apply this method to the present ternary system, contact angle measurements were performed on pristine films of PCDTBT, $\mathrm{PC}_{71} \mathrm{BM}$ and porphyrin 8 with deionized water and ethylene glycol (Figure S4, Table S1). The corresponding surface energy values (Table S1) were then calculated using the OWRK (Owen, Wendt, Rabel and Kaelble) method. ${ }^{[18]}$ The surface free energy of $\mathrm{Cu}(\mathrm{II})$-porphyrin $\mathbf{8}$ $\left(24 \mathrm{~mJ} / \mathrm{m}^{2}\right)$ was found to be closer to the value obtained for PCDTBT $\left(22 \mathrm{~mJ} / \mathrm{m}^{2}\right)$ than that of $\mathrm{PC}_{71} \mathrm{BM}\left(28 \mathrm{~mJ} / \mathrm{m}^{2}\right)$, a finding consistent with the porphyrin having an improved affinity for the PCDTBT phase. Whether the third component is suspended within the donor phase or located at the donor-acceptor interface can be determined by calculating the wetting coefficient $\left(\omega_{\mathrm{C}}\right)$ by application of Young's equation: $\omega_{\mathrm{C}}=\left(\gamma_{\mathrm{C}-\mathrm{B}}-\gamma_{\mathrm{C}-\mathrm{A}}\right) / \gamma_{\mathrm{A}-\mathrm{B}}$ in which $\mathrm{A}, \mathrm{B}$ and $\mathrm{C}$ are the respective phases and $\gamma_{\mathrm{X}-\mathrm{Y}}$ is the interfacial surface energy between components $\mathrm{X}$ 
and $Y .{ }^{[19]}$ The interfacial energy can be calculated using Neumann's equation: $\gamma_{X-Y}=\gamma_{X}+\gamma_{Y}$ $-2\left(\gamma_{\mathrm{X}} \gamma_{\mathrm{Y}}\right)^{0.5} \exp \left[-\beta\left(\gamma_{\mathrm{X}}-\gamma_{\mathrm{Y}}\right)^{2}\right]$, with $\beta=0.000115 \mathrm{~m}^{4} \mathrm{~mJ}^{-2}{ }^{[20]}$ If the obtained $\omega_{\mathrm{c}}>1$, component $\mathrm{C}$ will be located in domain $\mathrm{A}$, whereas if $\omega_{\mathrm{c}}<-1$, it will be located in domain $\mathrm{B}$. For intermediate values $\left(-1<\omega_{\mathrm{c}}<1\right)$, material $\mathrm{C}$ will be located at the interface of the two other components. From the surface energy values, a wetting coefficient of 0.33 was obtained, indicating that porphyrin $\mathbf{8}$ is preferentially located at the PCDTBT-PC ${ }_{71} \mathrm{BM}$ interface. Based on these results, and in combination with proper energy level alignment (as determined by cyclic voltammetry; Table S2, Figure S5), we propose that porphyrin 8 facilitates charge transfer between the respective components, resulting in elevated $J_{\mathrm{SC}}$ values. ${ }^{[7 \mathrm{~g}]}$

To verify the generality of the PCE increase seen upon the addition of metalloporphyrin derivative $\mathbf{8}$, this and related compounds were used to prepare ternary polymer solar cells containing a second selected low bandgap copolymer, PCPDT-DTTzTz (Figure 1). ${ }^{[16]}$ In an analogous fashion, the ternary blends PCPDT-DTTzTz:PC ${ }_{71} \mathrm{BM}$ :porphyrin were prepared in a 5:15:0.1 (wt\%) ratio. The $I-V$ characteristics of the resulting polymer solar cells are summarized in Table 2. Taken in concert, they provide evidence for a similar influence of the porphyrin derivatives on the final device performances, with increased $J_{\mathrm{SC}}$ values coming at the expense (in some cases) of the $V_{\mathrm{OC}}$ and/or the FF. Again, the $\mathrm{Cu}(\mathrm{II})$-porphyrins were the most effective additives as they resulted in an average PCE of $4.8 \%$ for the ternary blend with porphyrin 7 ( vs $4.5 \%$ for the reference device) (Figure S6). In contrast, the free-base compounds resulted in the lowest device efficiencies. In this case, however, the devices containing monosubstituted $\mathrm{Cu}(\mathrm{II})$-porphyrin 7 performed slightly better than those based on disubstituted $\mathrm{Cu}$ (II)-porphyrin 8 . In analogy to what was observed with the system containing PCDTBT, TEM (and SAED) analysis did not show meaningful differences in the active layer morphology upon the addition of the metalloporphyrin additives that maximized device performance (Figure S7, S8). 
Table 2. Summary of the $I-V$ characteristics of the PCPDT-DTTzTz:PC ${ }_{71} \mathrm{BM}$ polymer solar cells with and without incorporation of porphyrin derivatives 1-9.

\begin{tabular}{|c|c|c|c|c|c|c|}
\hline & Material blend & $J_{\mathrm{SC}} / \mathrm{mA} \mathrm{cm}^{-2}$ & $V_{\mathrm{OC}} / \mathrm{V}$ & FF & PCE(Ave) $/ \%^{a}$ & $\operatorname{PCE}($ Best $) / \%$ \\
\hline 1 & PCPDT-DTTzTz:PC ${ }_{71} \mathrm{BM}$ & $11.88( \pm 0.43)$ & $0.67( \pm 0.00)$ & $0.57( \pm 0.01)$ & $4.5( \pm 0.1)$ & 4.8 \\
\hline 2 & PCPDT-DTTzTz:PC ${ }_{71} \mathrm{BM}: 1$ & $12.10( \pm 0.44)$ & $0.57( \pm 0.01)$ & $0.37( \pm 0.01)$ & $2.6( \pm 0.1)$ & 2.8 \\
\hline 3 & PCPDT-DTTzTz:PC ${ }_{71} \mathrm{BM}: 2$ & $12.57( \pm 0.62)$ & $0.62( \pm 0.01)$ & $0.46( \pm 0.01)$ & $3.6( \pm 0.2)$ & 4.0 \\
\hline 4 & PCPDT-DTTzTz:PC ${ }_{71} \mathrm{BM}: 3$ & $12.49( \pm 0.93)$ & $0.64( \pm 0.01)$ & $0.54( \pm 0.01)$ & $4.3( \pm 0.3)$ & 4.8 \\
\hline 5 & PCPDT-DTTzTz:PC ${ }_{71} \mathrm{BM}: 4$ & $12.63( \pm 0.76)$ & $0.65( \pm 0.01)$ & $0.55( \pm 0.01)$ & $4.5( \pm 0.3)$ & 5.0 \\
\hline 6 & PCPDT-DTTzTz:PC ${ }_{71}$ BM:5 & $11.57( \pm 0.54)$ & $0.65( \pm 0.01)$ & $0.52( \pm 0.03)$ & $3.9( \pm 0.4)$ & 4.6 \\
\hline 7 & PCPDT-DTTzTz:PC ${ }_{71} \mathrm{BM}: 6$ & $12.13( \pm 0.68)$ & $0.66( \pm 0.00)$ & $0.53( \pm 0.01)$ & $4.2( \pm 0.2)$ & 4.5 \\
\hline 8 & PCPDT-DTTzTz:PC ${ }_{71} \mathrm{BM:7}$ & $12.55( \pm 0.71)$ & $0.66( \pm 0.01)$ & $0.58( \pm 0.01)$ & $4.8( \pm 0.2)$ & 5.2 \\
\hline 9 & PCPDT-DTTzTz:PC ${ }_{71} \mathrm{BM}: 8$ & $12.56( \pm 0.64)$ & $0.66( \pm 0.01)$ & $0.57( \pm 0.01)$ & $4.7( \pm 0.3)$ & 4.9 \\
\hline 10 & PCPDT-DTTzTz:PC ${ }_{71} \mathrm{BM}: 9$ & $12.45( \pm 0.36)$ & $0.65( \pm 0.01)$ & $0.55( \pm 0.01)$ & $4.5( \pm 0.1)$ & 4.6 \\
\hline
\end{tabular}

${ }^{a}$ Averaged values over at least 8 devices.

A noteworthy result for all of the porphyrin-based ternary organic solar cells examined, both the ones investigated in this study as well as the previous P3HT-based devices, ${ }^{[14]}$ is that the central metal ion has a major impact. Those devices containing $\mathrm{Cu}$ (II) species afforded the best results in all cases, although the corresponding absorption spectra, ionization potentials and electron affinities were similar for all metalloporphyrins studied. ${ }^{[14]}$ A recent study by Wang et al. also demonstrated that devices incorporating a $\mathrm{Cu}(\mathrm{II})$-porphyrin display a strong thermal stability enhancement, while showing initial PCE values that are retained or even slightly enhanced. ${ }^{[13 \mathrm{~b}]}$ The beneficial role of the $\mathrm{Cu}$ ion in terms of enhancing the efficiency and stability remains elusive at this stage; however, it may be related to the reduced affinity for fullerene (i.e., lower association constants) of $\mathrm{Cu}$-porphyrins as compared to their $\mathrm{Ni}, \mathrm{Zn}$, Co and free-base analogues. ${ }^{[21]}$ To the extent that this is true, it would support a rationale wherein the observed operational benefits reflect a direct relationship between the supramolecular porphyrin-fullerene $(\pi-\pi)$ interactions and device performance.

\section{Conclusions}

In conclusion, we have demonstrated the beneficial influence of certain metalloporphyrin derivatives when used as ternary blend components in the photoactive layer of bulk heterojunction low bandgap polymer:fullerene solar cells. The best systems, the copper complexes 7 and 8, provide a PCE increase of up to 16\% (compared to the value displayed by 
an analogous device containing a binary blend). It was found that these $\mathrm{Cu}(\mathrm{II})$-porphyrins showed the greatest benefit in the case of two low optical gap copolymers, PCDTBT and PCPDT-DTTzTz, as was also the case for the P3HT-based devices studied previously. From the AFM and TEM data, no distinct changes in the photoactive layer morphology were observed. Moreover, EQE measurements did not indicate any direct porphyrin photosensitizer contribution to the photocurrent generation. Nonetheless, surface free energy measurements and the resulting wetting coefficient provided support for the conclusion that $\mathrm{Cu}(\mathrm{II})$-porphyrin 8 is located at the interface of PCDTBT and $\mathrm{PC}_{71} \mathrm{BM}$. In combination with appropriately aligned energy levels, this leads us to suggest that the porphyrin improves charge transfer between the donor and acceptor components in the ternary blend film, resulting in enhanced $J_{\text {SC }}$ values. Further efforts will be directed toward gaining a deeper understanding of the determinants that underlie the observed efficiency enhancement, with a particular focus being placed on elucidating further the significant role played by the central metal ion.

\section{Experimental Section}

Materials: The following chemicals were obtained from commercial sources and used without further purification: PCDTBT (SolarisChem, $M_{\mathrm{n}}=79 \mathrm{kDa}, D=2.4$ ), $\mathrm{PC}_{71} \mathrm{BM}$ (Solenne BV, 99\%), PEDOT:PSS (Heraeus), o-dichlorobenzene (Aldrich, 99\%), chlorobenzene (Aldrich, 99.8\%), calcium (Alfa Aesar, 99\%) and aluminum (Kurt J. Lesker, 99.99\%). PCPDT-DTTzTz was prepared via a previously reported procedure. ${ }^{[16]}$

Porphyrin-terthiophene conjugates synthesis: The porphyrin compounds were synthesized via the procedure outlined below. ${ }^{[14,22]}$

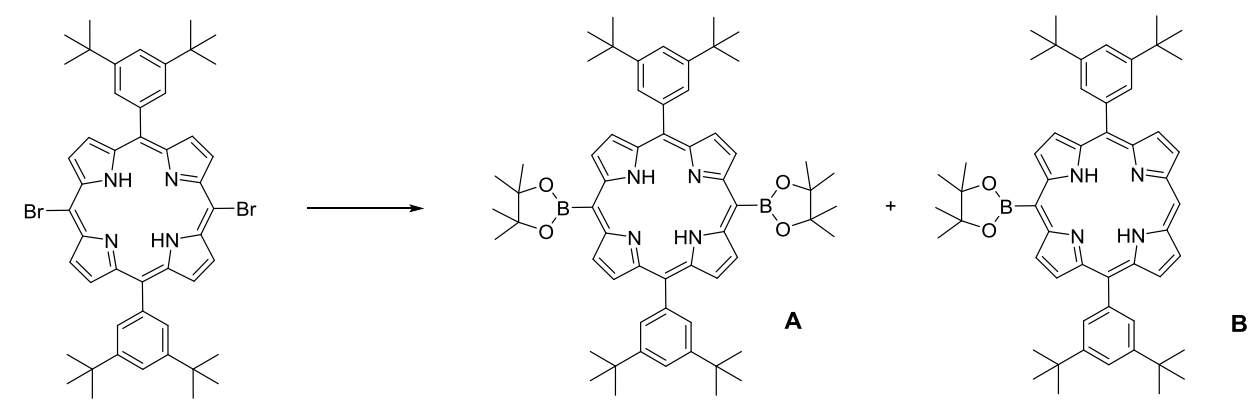

A solution of 5,15-dibromo-10,20-bis[3‘ $3^{‘}$-(di-tert-butyl)phenyl]porphyrin ${ }^{[23]}(0.200 \mathrm{~g}, 0.222$ mmol) and bis(triphenylphosphine)palladium(II) dichloride $(0.031 \mathrm{~g}, 44.6 \mu \mathrm{mol})$ in toluene $(20 \mathrm{~mL})$, THF $(20 \mathrm{~mL})$ and triethylamine $(4.5 \mathrm{~mL})$ was taken through 3 freeze-pump-thaw 
cycles. Pinacolborane $(1.13 \mathrm{~mL}, 7.77 \mathrm{mmol})$ was added and the resulting solution was heated to $60{ }^{\circ} \mathrm{C}$ overnight. The solution was cooled and then carefully quenched through the slow addition of water. The aqueous solution was removed and the remaining solution was dried $\left(\mathrm{Na}_{2} \mathrm{SO}_{4}\right)$ and the solvent was removed in vacuo. The crude material was then purified by column chromatography (silica gel, gradient 2:1 hexanes/dichloromethane to 1:1 hexanes/dichloromethane) to give the bis-boronate porphyrin $\mathbf{A}(0.068 \mathrm{~g}, 31 \%)$ and the monoboronate porphyrin $\mathbf{B}(0.038 \mathrm{~g}, 20 \%)$ as purple-red solids

A: $\mathrm{Mp}>350{ }^{\circ} \mathrm{C} ;{ }^{1} \mathrm{H}$ NMR $\left(400 \mathrm{MHz}, \mathrm{CDCl}_{3}\right) \delta 1.48(\mathrm{~s}, 36 \mathrm{H}), 1.68(\mathrm{~s}, 24 \mathrm{H}), 7.71(\mathrm{t}, J=2.0$ $\mathrm{Hz}, 2 \mathrm{H}), 7.82(\mathrm{~d}, J=2.0 \mathrm{~Hz}, 4 \mathrm{H}), 8.81(\mathrm{~d}, J=5.2 \mathrm{~Hz}, 4 \mathrm{H}), 9.73(\mathrm{~d}, J=5.2 \mathrm{~Hz}, 4 \mathrm{H}) ; \mathrm{HRMS}$ (MALDI-TOF): Calcd for $\mathrm{C}_{60} \mathrm{H}_{74} \mathrm{~B}_{2} \mathrm{~N}_{4} \mathrm{NiO}_{4}{ }^{+}(\mathrm{M})^{+}$994.5250, Found 994.5268.

B: $\mathrm{Mp}>350{ }^{\circ} \mathrm{C} ;{ }^{1} \mathrm{H}$ NMR $\left(400 \mathrm{MHz}, \mathrm{CDCl}_{3}\right) \delta 1.50(\mathrm{~s}, 36 \mathrm{H}), 1.71(\mathrm{~s}, 12 \mathrm{H}), 7.74(\mathrm{t}, J=2.0$ Hz, 2H), $7.88(\mathrm{~d}, J=2.0 \mathrm{~Hz}, 4 \mathrm{H}), 8.89(\mathrm{~d}, J=4.8 \mathrm{~Hz}, 2 \mathrm{H}), 8.90(\mathrm{~d}, J=5.2 \mathrm{~Hz}, 2 \mathrm{H}), 9.12(\mathrm{~d}, J$ $=4.4 \mathrm{~Hz}, 2 \mathrm{H}), 9.76(\mathrm{~d}, J=4.8 \mathrm{~Hz}, 2 \mathrm{H}), 9.83(\mathrm{~s}, 1 \mathrm{H})$; HRMS (MALDI-TOF): Calcd for $\mathrm{C}_{54} \mathrm{H}_{63} \mathrm{BN}_{4} \mathrm{NiO}_{2}^{+}(\mathrm{M})^{+} 868.4398$, Found 868.4407.
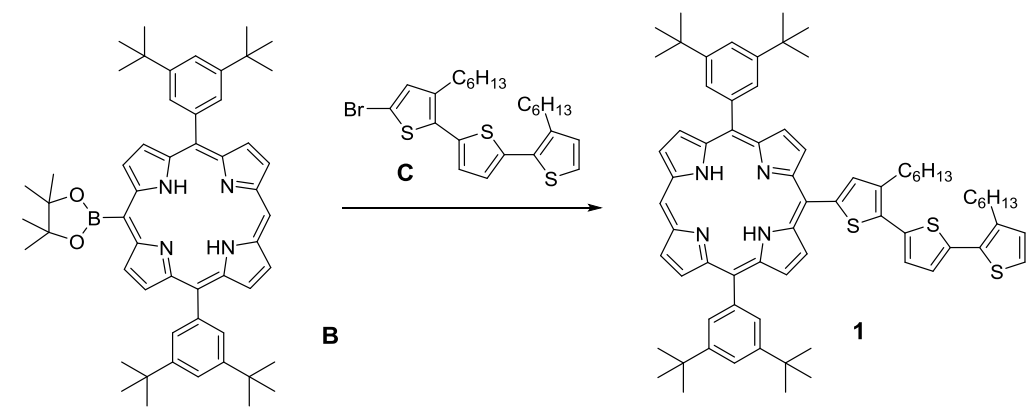

A solution of porphyrin $\mathbf{B}(0.072 \mathrm{~g}, 88.7 \mu \mathrm{mol})$, terthiophene bromide $\mathbf{C}^{[24]}(0.066 \mathrm{~g}, 133$ $\mu \mathrm{mol})$ and cesium carbonate $(0.346 \mathrm{~g}, 1.06 \mu \mathrm{mol})$ in toluene $(10 \mathrm{~mL})$ was taken through 3 freeze-pump-thaw cycles and was then warmed to $20{ }^{\circ} \mathrm{C}$. Tetrakis(triphenylphosphine)palladium(0) $(0.010 \mathrm{~g}, 8.87 \mu \mathrm{mol})$ was then added and the resulting solution was heated to $120{ }^{\circ} \mathrm{C}$ overnight. The solution was cooled and then filtered through celite. The solvent was removed in vacuo and the crude material was purified by column chromatography (silica gel, 1:2 dichloromethane/hexanes) to give free-base porphyrin $\mathbf{1}$ as a purple solid $(0.082 \mathrm{~g}, 84 \%)$.

$\mathrm{Mp}>350{ }^{\circ} \mathrm{C} ;{ }^{1} \mathrm{H}$ NMR (400 MHz, $\left.\mathrm{CDCl}_{3}\right) \delta-2.60$ (br s, 2H), 0.89 (q, $\left.J=7.2 \mathrm{~Hz}, 6 \mathrm{H}\right)$, 1.30-1.44 (m, 48H), 1.63-1.71 (m, 2H), 1.87-1.91 (m, 2H), $2.84(\mathrm{t}, J=8.0 \mathrm{~Hz}, 2 \mathrm{H}), 3.06(\mathrm{t}$, $J=8.0 \mathrm{~Hz}, 2 \mathrm{H}), 6.96(\mathrm{~d}, J=5.2 \mathrm{~Hz}, 1 \mathrm{H}), 7.13(\mathrm{~d}, J=3.6 \mathrm{~Hz}, 1 \mathrm{H}), 7.20(\mathrm{~d}, J=5.2 \mathrm{~Hz}, 1 \mathrm{H})$, $7.27(\mathrm{~d}, J=3.6 \mathrm{~Hz}, 1 \mathrm{H}), 7.58(\mathrm{~s}, 1 \mathrm{H}), 7.75(\mathrm{t}, J=2.0 \mathrm{~Hz}, 2 \mathrm{H}), 7.89(\mathrm{~d}, J=2.0 \mathrm{~Hz}, 4 \mathrm{H}), 8.86$ (d, $J=4.8 \mathrm{~Hz}, 2 \mathrm{H}), 8.92(\mathrm{~d}, J=4.8 \mathrm{~Hz}, 2 \mathrm{H}), 9.13$ (d, $J=4.8 \mathrm{~Hz}, 2 \mathrm{H}), 9.17$ (d, $J=4.8 \mathrm{~Hz}$, 
2H), 9.83 (s, 1H); HRMS (MALDI-TOF): Calcd for $\mathrm{C}_{72} \mathrm{H}_{85} \mathrm{~N}_{4} \mathrm{~S}_{3}{ }^{+}(\mathrm{M}+\mathrm{H})^{+}$1101.5931, Found 1101.5935.
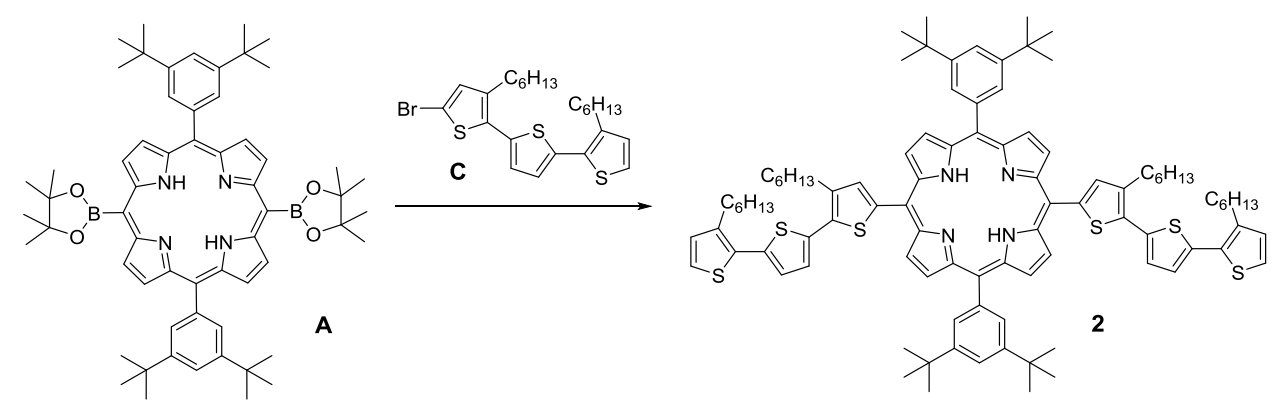

A solution of porphyrin A $(0.028 \mathrm{~g}, 29.9 \mu \mathrm{mol})$, terthiophene bromide $\mathbf{C}^{[24]}(0.037 \mathrm{~g}, 746$ $\mu \mathrm{mol})$ and cesium carbonate $(0.117 \mathrm{~g}, 359 \mu \mathrm{mol})$ in toluene $(10 \mathrm{~mL})$ was taken through 3 freeze-pump-thaw cycles and was then warmed to $20{ }^{\circ} \mathrm{C}$. Tetrakis(triphenylphosphine)palladium(0) (0.004 g, $2.99 \mu \mathrm{mol})$ was then added and the resulting solution was heated to $120{ }^{\circ} \mathrm{C}$ overnight. The solution was cooled and then filtered through celite. The solvent was removed in vacuo and the crude material was purified by column chromatography (silica gel, gradient hexanes to $20 \%$ dichloromethane/hexanes) to afford free-base porphyrin 2 as a purple solid $(0.014 \mathrm{~g}, 31 \%)$.

$\mathrm{Mp}>350{ }^{\circ} \mathrm{C} ;{ }^{1} \mathrm{H}$ NMR (400 MHz. $\mathrm{CDCl}_{3}$ ) $\delta-2.62$ (br s, 2H), 0.86-0.94 (m, 12H), 1.32-1.50 (m, 24H), $1.54(\mathrm{~s}, 36 \mathrm{H}), 1.69-1.71(\mathrm{~m}, 4 \mathrm{H}), 1.96-1.98(\mathrm{~m}, 4 \mathrm{H}), 2.86(\mathrm{t}, J=7.6 \mathrm{~Hz}, 4 \mathrm{H}), 3.13$ $(\mathrm{t}, J=7.8 \mathrm{~Hz}, 4 \mathrm{H}), 6.98(\mathrm{~d}, J=5.2 \mathrm{~Hz}, 2 \mathrm{H}), 7.17(\mathrm{~d}, J=3.6 \mathrm{~Hz}, 2 \mathrm{H}), 7.22(\mathrm{~d}, J=5.2 \mathrm{~Hz}, 2 \mathrm{H})$, $7.33(\mathrm{~d}, J=3.6 \mathrm{~Hz}, 2 \mathrm{H}), 7.76(\mathrm{~s}, 2 \mathrm{H}), 7.82(\mathrm{t}, J=2.0 \mathrm{~Hz}, 2 \mathrm{H}), 8.08(\mathrm{~d}, J=2.0 \mathrm{~Hz}, 4 \mathrm{H}), 8.90$ (d, $J=4.8 \mathrm{~Hz}, 4 \mathrm{H}), 9.22(\mathrm{~d}, J=4.8 \mathrm{~Hz}, 4 \mathrm{H})$; HRMS (MALDI-TOF): Calcd for $\mathrm{C}_{96} \mathrm{H}_{115} \mathrm{~N}_{4} \mathrm{~S}_{6}{ }^{+}$ $(\mathrm{M}+\mathrm{H})^{+}$1515.7441, Found 1515.7492.
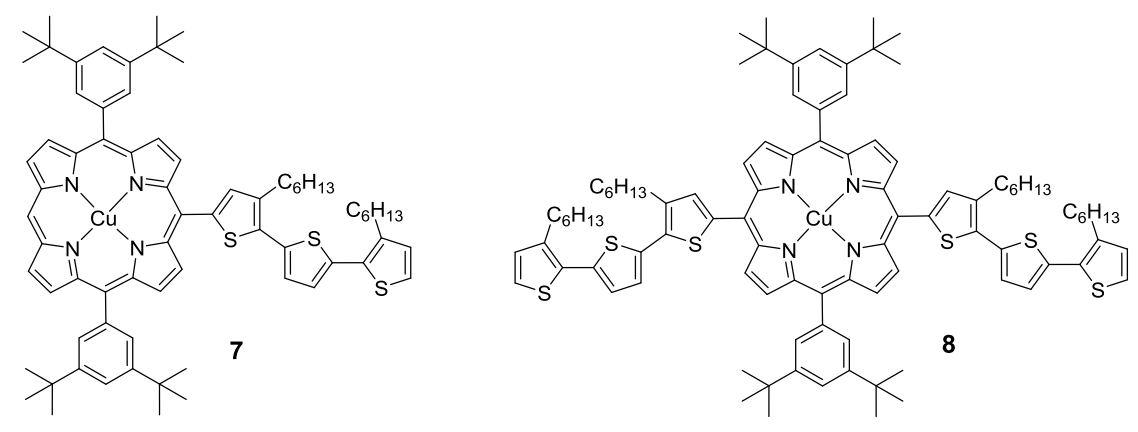

A solution of free-base porphyrin $2(0.017 \mathrm{~g}, 11 \mu \mathrm{mol})$ in chloroform $(4 \mathrm{~mL})$ was degassed with $\mathrm{N}_{2}$ for 15 min before a solution of $\mathrm{Cu}(\mathrm{OAc})_{2} \cdot \mathrm{H}_{2} \mathrm{O}(0.224 \mathrm{~g}, 1.12 \mathrm{mmol})$ in methanol (4 $\mathrm{mL}$ ) was added. The resulting solution was stirred at room temperature for $3 \mathrm{~h}$ and then diluted with chloroform and washed with water. The organic layer was dried with $\mathrm{MgSO}_{4}$ and 
the solvent was removed in vacuo. The crude material was purified by column chromatography (silica gel, gradient hexanes to $5 \%$ dichloromethane/hexanes) to afford $\mathrm{Cu}$ (II)-porphyrin 8 as a dark solid in a near-quantitative yield $(0.017 \mathrm{~g}, 96 \%)$. The same procedure was also applied for the insertion of $\mathrm{Cu}$ into the monosubstituted free-base porphyrin 1.

$\mathrm{Cu}$ (II) porphyrin 7: $\mathrm{Mp}>350{ }^{\circ} \mathrm{C}$; HRMS (MALDI-TOF): Calcd for $\mathrm{C}_{72} \mathrm{H}_{82} \mathrm{~N}_{4} \mathrm{~S}_{3} \mathrm{Cu}^{+}(\mathrm{M})^{+}$ 1161.4998, Found 1161.4978.

$\mathrm{Cu}$ (II) porphyrin 8: $\mathrm{Mp}>350{ }^{\circ} \mathrm{C}$; HRMS (MALDI-TOF): Calcd for $\mathrm{C}_{96} \mathrm{H}_{112} \mathrm{~N}_{4} \mathrm{~S}_{6} \mathrm{Cu}_{2}{ }^{+}(\mathrm{M})^{+}$ 1575.6507, Found 1575.6451.

UV-Vis Characterization: UV-Vis absorption spectra were recorded with an Agilent Cary 500 Scan UV-Vis-NIR spectrometer in a continuous run from 200 to $800 \mathrm{~nm}$ at a scan rate of 600 $\mathrm{nm} / \mathrm{min}$. The thin films for the solid-state UV-Vis measurements were prepared by drop casting chloroform solutions of the pure compounds and blends.

Electrochemical Characterization: Cyclic voltammetry (CV) measurements were carried out with an Autolab PGSTAT 30 potentiostat from Eco Chemie. A three-electrode microcell setup was used with $\mathrm{Ag} / \mathrm{Ag}^{+}\left(\mathrm{Ag}\right.$ wire dipped in a solution containing $0.01 \mathrm{M} \mathrm{AgNO}_{3}$ in $0.1 \mathrm{M}$ $\mathrm{NBu}_{4} \mathrm{PF}_{6}$ prepared in anhydrous acetonitrile) as reference electrode, a Pt wire as working electrode and a Pt wire as counter electrode. The system was calibrated against the ferrocene/ferrocenium redox couple $\left(\mathrm{Fc} / \mathrm{Fc}^{+}\right)$. A solution containing 0.1 M tetrabutylammonium hexafluorophosphate $\left(\mathrm{NBu}_{4} \mathrm{PF}_{6}\right)$ in anhydrous acetonitrile (films) or dichloromethane (solutions) was used as supporting electrolyte. To remove oxygen from the electrolyte, the solution was bubbled with Ar prior to each experiment. The experiments were carried out under a curtain of Ar to prevent atmospheric gases from redissolving into the solution during the experiments. The products to be analyzed were dissolved in the electrolyte solution or applied on the working electrode surface by dipping. Cyclic voltammograms were recorded at a scan rate of $100 \mathrm{mV} \cdot \mathrm{s}^{-1}$ and $300 \mathrm{mV} \cdot \mathrm{s}^{-1}$. The HOMO and LUMO energy levels of the products were estimated using the $\mathrm{CV}$ data. For the conversion of $\mathrm{V}$ to $\mathrm{eV}$, the onset potential of the oxidation/reduction peak was used and referenced to $\mathrm{Fc} / \mathrm{Fc}^{+}$, which is estimated to have a work function value of $-4.98 \mathrm{eV}$ vs vacuum.

Formula for the conversion from V to eV: $E(\mathrm{HOMO} / \mathrm{LUMO})(\mathrm{eV})=-1 *\left(E_{\text {onset }}^{\text {ox/red }} v s\right.$ $\mathrm{Ag} / \mathrm{AgNO}_{3}-E_{\text {onset }}^{\mathrm{Fc} / \mathrm{Fc}+}$ vs $\left.\mathrm{Ag} / \mathrm{AgNO}_{3}\right)-4.98$. The correction factor of 4.98 is set by using a potential value of $0.31 \mathrm{eV}$ for $\mathrm{Fc} / \mathrm{Fc}^{+}$vs $\mathrm{SCE}^{[25 \mathrm{a}]}$ and a potential value of $4.68 \mathrm{eV}$ for SCE $v s$ $\operatorname{vacuum}^{[25 b]}$. 
OPV Device Fabrication: Indium tin oxide (ITO) coated glass substrates were washed through ultrasonication in a solution consisting of powdered labware detergent, water, acetone and isopropyl alcohol for 15, 10, 5 and $5 \mathrm{~min}$, respectively, dried with $\mathrm{N}_{2}$, and then treated with $\mathrm{UV}_{3} \mathrm{O}_{3}$ for $15 \mathrm{~min}$. A thin layer $(\sim 30 \mathrm{~nm})$ of PEDOT:PSS (poly[3,4ethylenedioxythiophene]:poly[4-styrenesulphonate]) was spin-coated onto the cleaned substrates at a spin rate of $3000 \mathrm{rpm}$ for $60 \mathrm{~s}$, and the film was dried in air at $130{ }^{\circ} \mathrm{C}$ for 15 min. Further processing and characterization was carried out in an inert atmosphere in a glovebox $\left(\mathrm{O}_{2} / \mathrm{H}_{2} \mathrm{O}<0.1 \mathrm{ppm}\right)$. To prepare the ternary blend solutions, the porphyrin compounds were first dissolved in a $2 \mathrm{mg} / \mathrm{mL}$ concentration in the corresponding processing solvents, from which $50 \mu \mathrm{L}$ was then added to the polymer:PC ${ }_{71} \mathrm{BM}$ blends. As such, active layers consisting of PCDTBT:PC ${ }_{71}$ BM:porphyrin (1:4 PCDTBT:PC ${ }_{71} \mathrm{BM}(\mathrm{wt} / \mathrm{wt})$ ratio, total concentration $25 \mathrm{mg} / \mathrm{mL}$ in $o$-dichlorobenzene, heated with stirring at $75{ }^{\circ} \mathrm{C}$ overnight) or PCPDT-DTTzTz:PC ${ }_{71} \mathrm{BM}$ :porphyrin (1:3 PCPDT-DTTzTz:PC ${ }_{71} \mathrm{BM}$ (wt/wt) ratio, total concentration $20 \mathrm{mg} / \mathrm{mL}$ in chlorobenzene) were spin-coated on top of the PEDOT:PSS films. Finally, calcium $(20 \mathrm{~nm})$ and aluminum $(80 \mathrm{~nm})$ were thermally evaporated through a shadow mask to afford device areas of $25 \mathrm{~mm}^{2}$.

OPV Device Characterization: The photovoltaic response was measured using a Newport class A solar simulator (model 91195A) calibrated with a silicon solar cell to give an AM 1.5 spectrum. EQE measurements were performed with a Newport Apex illuminator (100 W Xenon lamp, 6257) as light source, a Newport Cornerstone $130^{\circ}$ monochromator and a Stanford SR830 lock-in amplifier for the current measurements. A silicon FDS100-CAL photodiode was employed as a reference cell. For AFM imaging, a Bruker Multimode 8 AFM was used in PeakForce tapping mode, employing ScanAsyst. The images were produced with a silicon tip on a nitride lever with a spring constant of $4 \mathrm{~N} / \mathrm{m}$. The TEM measurements were performed on a FEI Tecnai Spirit using an accelerating voltage of $120 \mathrm{kV}$. By washing away the PEDOT:PSS layer with water, freestanding films were obtained.

Mobility Measurements: FETs were prepared by spin casting pure polymer and polymer:metalloporphyrin solutions in $o$-dichlorobenzene $(10 \mathrm{mg} / \mathrm{mL})$ on substrates with prepatterned source and drain Ti/Au $(10 / 100 \mathrm{~nm})$ contacts, obtained from Philips. The dielectric (200 $\mathrm{nm}$ of $\mathrm{SiO}_{2}$, thermally grown on top of the highly $\mathrm{n}$-doped gate) was passivated by a layer of hexamethyldisilazane (HMDS), resulting in better performing transistors. All FET preparation and characterization was carried out in a $\mathrm{N}_{2}$ filled glovebox. Reported hole mobility values are averaged over 4 transistors with a channel length of $10 \mu \mathrm{m}$. 
Photo-CELIV signals were registered from solar cell devices prepared by spin casting the active layers from solutions with a concentration two times as high as the ones used for the optimal solar cells. The used setup comprised a pulsed laser (Continuum minilite II, 532nm), a Tektronix TDS 620B oscilloscope and a Tektronix AFG3101 function generator. The samples were placed in a sample holder filled with nitrogen to avoid exposure to ambient air.

Contact angle measurements: Contact angle measurements (sessile drop method) were performed on a DataPhysics OCA-15 plus with deionized $\mathrm{H}_{2} \mathrm{O}$ and ethylene glycol.

\section{Acknowledgements}

This work was supported by the IAP 7/05 project FS2 (Functional Supramolecular Systems), granted by the Science Policy Office of the Belgian Federal Government (BELSPO). We are also grateful for financial support by the Research Program of the Research Foundation Flanders (FWO) (projects G.0415.14N, G.0B67.15N and M.ERA-NET project RADESOL). MK acknowledges the Agency for Innovation by Science and Technology in Flanders (IWT) for his PhD grant. CWB is grateful to the Institute for Basic Science (IBS-R019-D1) and the BK21 Plus Program as funded by the Ministry of Education and the National Research Foundation of Korea for their generous financial support. The work in Austin was supported by the U.S. National Science Foundation (grant CHE-1402004 to JLS).

\section{References}

[1] a) B. Kippelen, J.-L. Brédas, Energy Environ. Sci. 2009, 2, 251; b) R. Søndergaard, M. Hösel, D. Angmo, T. T. Larsen-Olsen, F. C. Krebs, Mater. Today 2012, 15, 36; c) Y. Su, S. Lan, K. Wei, Mater. Today 2012, 15, 554; d) L. Dou, J. You, Z. Hong, Z. Xu, G. Li, R. A. Street, Y. Yang, Adv. Mater. 2013, 25, 6642; e) S. Lizin, S. Van Passel, E. De Schepper, W. Maes, L. Lutsen, J. Manca, D. Vanderzande, Energy Environ. Sci. 2013, 6, 3136; f) K. A. Mazzio, C. K. Luscombe, Chem. Soc. Rev. 2015, 44, 78.

[2] Reviews on BHJ polymer solar cells: a) G. Dennler, M. C. Scharber, C. J. Brabec, Adv. Mater. 2009, 21, 1323; b) A. J. Heeger, Adv. Mater. 2014, 26, 10; c) L. Lu, T. Zheng, Q. Wu, A. M. Schneider, D. Zhao, L. Yu, Chem. Rev. 2015, 115, 12666.

[3] Top efficiency BHJ polymer solar cells: a) L. Dou, C.-C. Chen, K. Yoshimura, K. Ohya, W.-H. Chang, J. Gao, Y. Liu, E. Richard, Y. Yang, Macromolecules 2013, 46, 3384; b) I. 
Osaka, T. Kakara, N. Takemura, T. Koganezawa, K. Takimiya, J. Am. Chem. Soc. 2013, 135, 8834; c) Y. Deng, J. Liu, J. Wang, L. Liu, W. Li, H. Tian, X. Zhang, Z. Xie, Y. Geng, F. Wang, Adv. Mater. 2014, 26, 471; d) M. Zhang, X. Guo, S. Zhang, J. Hou, Adv. Mater. 2014, 26, 1118; e) L. Ye, S. Zhang, W. Zhao, H. Yao, J. Hou, Chem. Mater. 2014, 26, 3603; f) Y. Liu, J. Zhao, Z. Li, C. Mu, W. Ma, H. Hu, K. Jiang, H. Lin, H. Ade, H. Yan, Nat. Commun. 2014, 5, 5293; g) Z. He, B. Xiao, F. Liu, H. Wu, Y. Yang, S. Xiao, C. Wang, T. P. Russell, Y. Cao, Nat. Photon. 2015, 9, 174; h) J. Subbiah, B. Purushothaman, M. Chen, T. Qin, M. Gao, D. Vak, F. H. Scholes, X. Chen, S. E. Watkins, G. J. Wilson, A. B. Holmes, W. W. H. Wong, D. J. Jones, Adv. Mater. 2015, 27, 702; i) G. Pirotte, J. Kesters, P. Verstappen, S. Govaerts, J. Manca, L. Lutsen, D. Vanderzande, W. Maes, ChemSusChem 2015, 8, 3228; j) W. Yue, R. Shahid Ashraf, C. B. Nielsen, E. Collado-Fregoso, M. R. Niazi, S. Amber Yousaf, M. Kirkus, H.-Y. Chen, A. Amassian, J. R. Durrant, I. McCulloch, Adv. Mater. 2015, 27, 4702.

[4] a) J. K. Lee, W. L. Ma, C. J. Brabec, J. Yuen, J. S. Moon, J. Y. Kim, K. Lee, G. C. Bazan, A. J. Heeger, J. Am. Chem. Soc. 2008, 130, 3619; b) H.-C. Liao, C.-C. Ho, C.-Y. Chang, M.H. Jao, S. B. Darling, W.-F. Su, Mater. Today 2013, 9, 326; c) T. Wang, A. J. Pearson, D. G. Lidzey, J. Mater. Chem. C 2013, 1, 7266.

[5] a) Z. He, C. Zhong, X. Huang, W.-Y. Wong, H. Wu, L. Chen, S. Su, Y. Cao, Adv. Mater. 2011, 23, 4636; b) S. Liu, K. Zhang, J. Lu, J. Zhang, H.-L. Yip, F. Huang, Y. Cao, J. Am. Chem. Soc. 2013, 135, 15326; c) J. Kesters, T. Ghoos, H. Penxten, J. Drijkoningen, T. Vangerven, D. M. Lyons, B. Verreet, T. Aernouts, L. Lutsen, D. Vanderzande, J. Manca, W. Maes, Adv. Energy Mater. 2013, 3, 1180; d) M. Vasilopoulou, D. G. Georgiadou, A. M. Douvas, A. Soultati, V. Constantoudis, D. Davazoglou, S. Gardelis, L. C. Palilis, M. Fakis, S. Kennou, T. Lazarides, A. G. Coutsolelos, P. Argitis, J. Mater. Chem. A, 2014, 2, 182; e) Q. Bao, X. Liu, E. Wang, J. Fang, F. Gao, S. Braun, M. Fahlman, Adv. Mater. Interfaces 2015, 2, 1500204; f) J. Kesters, S. Govaerts, G. Pirotte, J. Drijkoningen, M. Chevrier, N. Van den Brande, X. Liu, M. Fahlman, B. Van Mele, L. Lutsen, D. Vanderzande, J. Manca, S. Clément, E. Von Hauff, W. Maes, ACS Appl. Mater. Interfaces 2016, 8, 6309.

[6] a) J. You, L. Dou, K. Yoshimura, T. Kato, K. Ohya, T. Moriarty, K. Emery, C.-C. Chen, J. Gao, G. Li, Y. Yang, Nat. Commun. 2013, 4, 1446; b) W. Li, A. Furlan, K. H. Hendriks, M. M. Wienk, R. A. J. Janssen, J. Am. Chem. Soc. 2013, 135, 5529; c) H. Zhou, Y. Zhang, C.-K. Mai, S. D. Collins, G. C. Bazan, T.-Q. Nguyen, A. J. Heeger, Adv. Mater. 2015, 27, 1767.

[7] a) L. Yang, L. Yan, W. You, J. Phys. Chem. Lett. 2013, 4, 1802; b) M. Koppe, H.-J. Egelhaaf, E. Clodic, M. Morana, L. Luër, A. Troeger, V. Sgobba, D. M. Guldi, T. Ameri, C. J. 
Brabec, Adv. Energy Mater. 2013, 3, 949; c) T. Ameri, P. Khoram, J. Min, C. J. Brabec, Adv. Mater. 2013, 25, 4245; d) L. Lu, T. Xu, W. Chen, E. S. Landry, L. Yu, Nat. Photonics 2014, 8, 716; e) J. Zhang, Y. Zhang, J. Fang, K. Lu, Z. Wang, W. Ma, Z. Wei, J. Am. Chem. Soc. 2015, 137, 8176; f) B. M. Savoie, S. Dunaisky, T. J. Marks, M. A. Ratner, Adv. Energy Mater. 2015, 5, 1400891; g) L. Lu, M. A. Kelly, W. You, L. Yu, Nat. Photon. 2015, 9, 491.

[8] a) A. Yella, H.-W. Lee, H. N. Tsao, C. Yi, A. K. Chandiran, Md. K. Nazeeruddin, E. W.G. Diau, C.-Y. Yeh, S. M. Zakeeruddin, M. Grätzel, Science 2011, 334, 629; b) L.-L. Li, E.W.-G. Diau, Chem. Soc. Rev. 2013, 42, 291; c) S. Matthew, A. Yella, P. Gao, R. HumphryBaker, B. F. Curchod, N. Ashari-Astani, I. Tavernelli, U. Rothlisberger, M. K. Nazeeruddin, M. Grätzel, Nat. Chem. 2014, 6, 242.

[9] Reviews on the application of porphyrins and phthalocyanines in photovoltaic devices: a) M. G. Walter, A. B. Rudine, C. C. Wamser, J. Porphyrins Phthalocyanines 2010, 14, 759; b) M. V. Martinez-Diaz, G. de la Torre, T. Torres, Chem. Commun. 2010, 46, 7090; c) H. Imahori, T. Umeyama, K. Kurotobi, Y. Takano, Chem. Commun. 2012, 48, 4032; d) J. Kesters, P. Verstappen, M. Kelchtermans, L. Lutsen, D. Vanderzande, W. Maes, Adv. Energy Mater. 2015, 5, 1500218.

[10] a) J. Hatano, N. Obata, S. Yamaguchi, T. Yasuda, Y. Matsuo, J. Mater. Chem. 2012, 22, 19258; b) T. Kengthanomma, P. Thamyongkit, J. Gasiorowski, A. M. Ramil, N. S. Sariciftci, J. Mater. Chem. A 2013, 1, 10524; c) G. D. Sharma, D. D. Daphnomili, S. Biswas, A. G. Coutsolelos, Org. Electron. 2013, 14, 1811; d) Y.-H. Chao, J.-F. Jheng, J.-S. Wu, K.-Y. Wu, H.-H. Peng, M.-C. Tsai, C.-L. Wang, Y.-N. Hsiao, C.-L. Wang, C.-Y. Lin, C.-S. Hsu, Adv. Mater. 2014, 26, 5205; e) H. Qin, L. Li, F. Guo, S. Su, J. Peng, Y. Cao, X. Peng, Energy Environ. Sci. 2014, 7, 1397; f) L. Wang, S. Shi, D. Ma, S. Chen, C. Gao, M. Wang, K. Shi, Y. Li, X. Li, H. Wang, Macromolecules 2015, 48, 287; g) C. V. Kumar, L. Cabau, E. N. Koukaras, G. D. Sharma, E. Palomares, Nanoscale 2015, 7, 179; h) S. Arrechea, A. MolinaOntoria, A. Aljarilla, P. de la Cruz, F. Langa, L. Echegoyen, Dyes Pigments 2015, 121, 109; i) K. Gao, L. Li, T. Lai, L. Xiao, Y. Huang, F. Huang, J. Peng, Y. Cao, F. Liu, T. P. Russell, R. A. J. Janssen, X. Peng, J. Am. Chem. Soc. 2015, 137, 7282; j) S. Chen, L. Xiao, X. Zhu, X. Peng, W.-K. Wong, W.-Y. Wong, Chem. Commun. 2015, 51, 14439.

[11] C.-L. Wang, W.-B. Zhang, R. M. Van Horn, Y. Tu, X. Gong, S. Z. D. Cheng, Y. Sun, M. Tong, J. Seo, B. B. Y. Hsu, A. J. Heeger, Adv. Mater. 2011, 23, 2951. 
[12] a) P. C. Dastoor, C. R. McNeill, H. Frohne, C. J. Foster, B. Dean, C. J. Fell, W. J. Belcher, W. M. Campbell, D. L. Officer, I. M. Blake, P. Thordarson, M. J. Crossley, N. S. Hush, J. R. Reimers, J. Phys. Chem. C 2007, 111, 15415; b) W. J. Belcher, K. I. Wagner, P. C. Dastoor Sol. Energy Mater. Sol. Cells 2007, 91, 447; c) K. B. Burke, W. J. Belcher, L. Thomsen, B. Watts, C. R. McNeill, H. Ade, P. C. Dastoor, Macromolecules 2009, 42, 3098; d) N. Cooling, K. B. Burke, X. Zhou, S. J. Lind, K. C. Gordon, T. W. Jones, P. C. Dastoor, W. J. Belcher, Sol. Energy Mater. Sol. Cells 2011, 95, 1767; e) N. A. Cooling, X. Zhou, T. A. Sales, S. E. Sauer, S. J. Lind, K. C. Gordon, T. W. Jones, K. B. Burke, P. C. Dastoor, W. J. Belcher, Sol. Energy Mater. Sol. Cells 2012, 98, 308.

[13] a) S. Wang, Y. Qu, S. Li, F. Ye, Z. Chen, X. Yang, Adv. Funct. Mater. 2015, 25, 748; b) S. Wang, M. Wang, Z. Chen, X. Yang, J. Mater. Chem. A 2015, 3, 21051.

[14] D. M. Lyons, J. Kesters, W. Maes, C. W. Bielawski, J. L. Sessler, Synth. Met. 2013, 178, 56.

[15] a) S. Wakim, S. Beaupré, N. Blouin, B.-R. Aich, S. Rodman, R. Gaudiana, Y. Tao, M. Leclerc, J. Mater. Chem. 2009, 19, 5351; b) S. Beaupré, M. Leclerc, J. Mater. Chem. A 2013, $1,11097$.

[16] S. Van Mierloo, A. Hadipour, M.-J. Spijkman, N. Van den Brande, B. Ruttens, J. Kesters, J. D’Haen, G. Van Assche, D. M. de Leeuw, T. Aernouts, J. Manca, L. Lutsen, D. J. Vanderzande, W. Maes, Chem. Mater. 2012, 24, 587.

[17] S. Honda, H. Ohkita, H. Benten, S. Ito, Adv. Energy. Mater. 2011, 1, 588.

[18] a) D. Owens, R. Wendt, J. Appl. Polym. Sci. 1969, 13, 1741; b) D. H. Kaelble, J. Adhesion 1970, 2, 66; c) W. Rabel, Farbe und Lack 1971, 77, 997.

[19] M. Sumita, K. Sakata, S. Asai, K. Miyasaka, H. Nakagawa, Polym. Bull. 1991, 25, 265.

[20] D. Li, W. Neumann, J. Colloid Interf. Sci. 1990, 137, 304.

[21] a) J. Y. Zheng, K. Tashiro, Y. Hirabayashi, K. Kinbara, K. Saigo, T. Aida, S. Sakamoto, K. Yamaguchi, Angew. Chem. Int. Ed. 2001, 40, 1857; b) A. Hosseini, S. Taylor, G. Accorsi, N. Armaroli, C. A. Reed, P. D. W. Boyd, J. Am. Chem. Soc. 2006, 128, 15903.

[22] D. M. Lyons, R. J. Ono, C. W. Bielawski, J. L. Sessler, J. Mater. Chem. 2012, 22, 18956.

[23] T. S. Balaban, R. Goddard, M. Linke-Schaetzel, J.-M. Lehn, J. Am. Chem. Soc. 2003, 125, 4233. 
[24] S. Destri, D. R. Ferro, I. A. Khotina, W. Porzio, A. Farina, Macromol. Chem. Phys. 1998, 199, 1973.

[25] a) J. Bard, L. R. Faulkner, Electrochemical methods: fundamentals and applications, $2^{\text {nd }}$ Ed., Wiley, 2001; b) S. Trasatti, Pure Appl. Chem. 1986, 58, 955. 